\title{
Corrosion behavior of metallic alloys in molten chloride salts for thermal energy storage in concentrated solar power plants - A review
}

\author{
Wenjin Ding ${ }^{\mathrm{a},{ }^{*}}$, Alexander Bonk ${ }^{\mathrm{a}}$, Thomas Bauer ${ }^{\mathrm{b}}$ \\ a Institute of Engineering Thermodynamics, German Aerospace Center (DLR), Stuttgart, Germany \\ ${ }^{b}$ Institute of Engineering Thermodynamics, German Aerospace Center (DLR), Cologne, Germany \\ ${ }^{*}$ Corresponding author. Tel.: +49 2203601 3162. E-mail address: wenjin.ding@dlr.de.
}

\begin{abstract}
Recently, more and more attention is paid on applications of molten chlorides in concentrated solar power (CSP) plants as high-temperature thermal energy storage (TES) and heat transfer fluid (HTF) materials due to their high thermal stability limits and low prices, compared to the commercial TES/HTF materials in CSP - nitrate salt mixtures. A higher TES/HTF operating temperature leads to higher efficiency of thermal to electrical energy conversion of the power block in CSP, however causes additional challenges, particularly increased corrosiveness of metallic alloys used as containers and structural materials. Thus, it is essential to study corrosion behaviors and mechanisms of metallic alloys in molten chlorides at operating temperatures $\left(500-800^{\circ} \mathrm{C}\right)$ for realizing the commercial application of molten chlorides in CSP. The results of studies on hot corrosion of metallic alloys in molten chlorides are reviewed to understand their corrosion behaviors and mechanisms under various conditions (e.g., temperature, atmosphere). Emphasis has also been given on salt purification to reduce corrosive impurities in molten chlorides and development of electrochemical techniques to in-situ monitor corrosive impurities in molten chlorides, in order to efficiently control corrosion rates of metallic alloys in molten chlorides to meet the requirements of industrial applications.
\end{abstract}

\section{Keywords}

Corrosion mechanisms, impurities, metallic corrosion, salt purification, electrochemical techniques. 


\section{1. Introduction}

2 Molten chlorides have wide applications in industrial processes, e.g., as electrolytes in hightemperature electrochemical plating and extraction of metals such as $\mathrm{Li}, \mathrm{Na}, \mathrm{Ca}$ and $\mathrm{Mg}$ [1-3]. Recently, more and more attention is paid on their promising applications as hightemperature thermal energy storage (TES) and heat transfer fluid (HTF) materials in concentrated solar power (CSP) plants [4-5] due to their good thermophysical properties and low prices. Over the course of the SunShot Initiative, the U.S. Department of Energy has supported the molten chloride salt development for the next generation CSP [4].

CSP technology is emerging as one important technology in the future renewable energy system. It is reported that global installed CSP-capacity has increased nearly fifteen-fold from 2005 to 2015 (up to 4.8 Gigawatts) and grew at an average rate of 50 percent per year from 2010 to 2015 (see Figure 18 in [6]). In CSP plants as illustrated in Figure 1, inexpensive storage of the heat from sunlight in TES materials such as molten salts allows them to generate dispatchable power during the absence of sunlight and adds value to such power plants. In commercial CSP plants, a non-eutectic salt mixture of 60 wt\% Sodium Nitrate and $40 \mathrm{wt} \%$ Potassium Nitrate, commonly known as Solar Salt, is typically utilized as the TES material. For instance, the 110-MWe Crescent Dunes tower CSP plant (see Figure 2) in Nevada, USA, uses $\sim 32000$ tons Solar Salt for 10 hours of storage and realizes an annual capacity factor of $52 \%$. Figure 3 shows a molten salt storage tank (container) for this CSP plant, which has huge size, 12.2 meters tall and 42.7 meters in diameter.

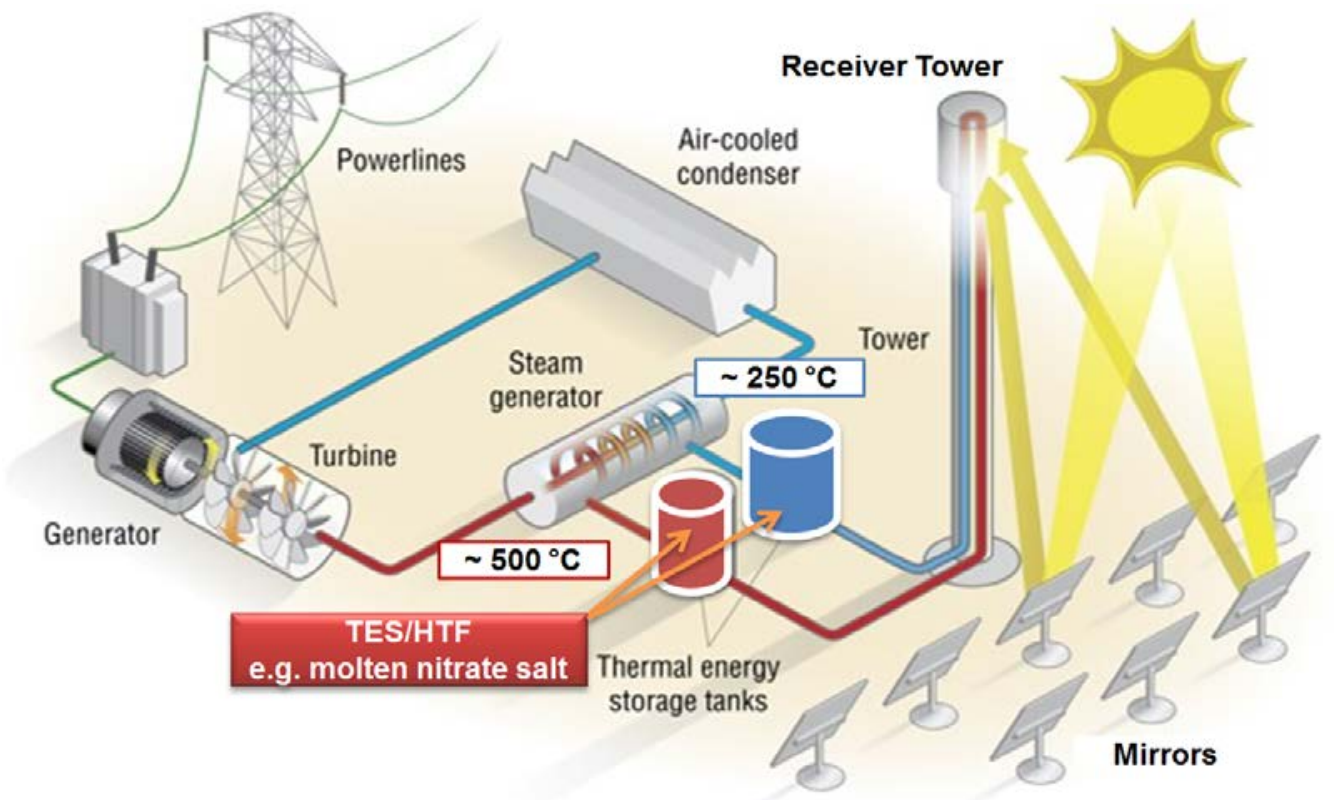

Figure 1: Concentrated solar power plants with molten salts as TES and HTF materials (source: US 


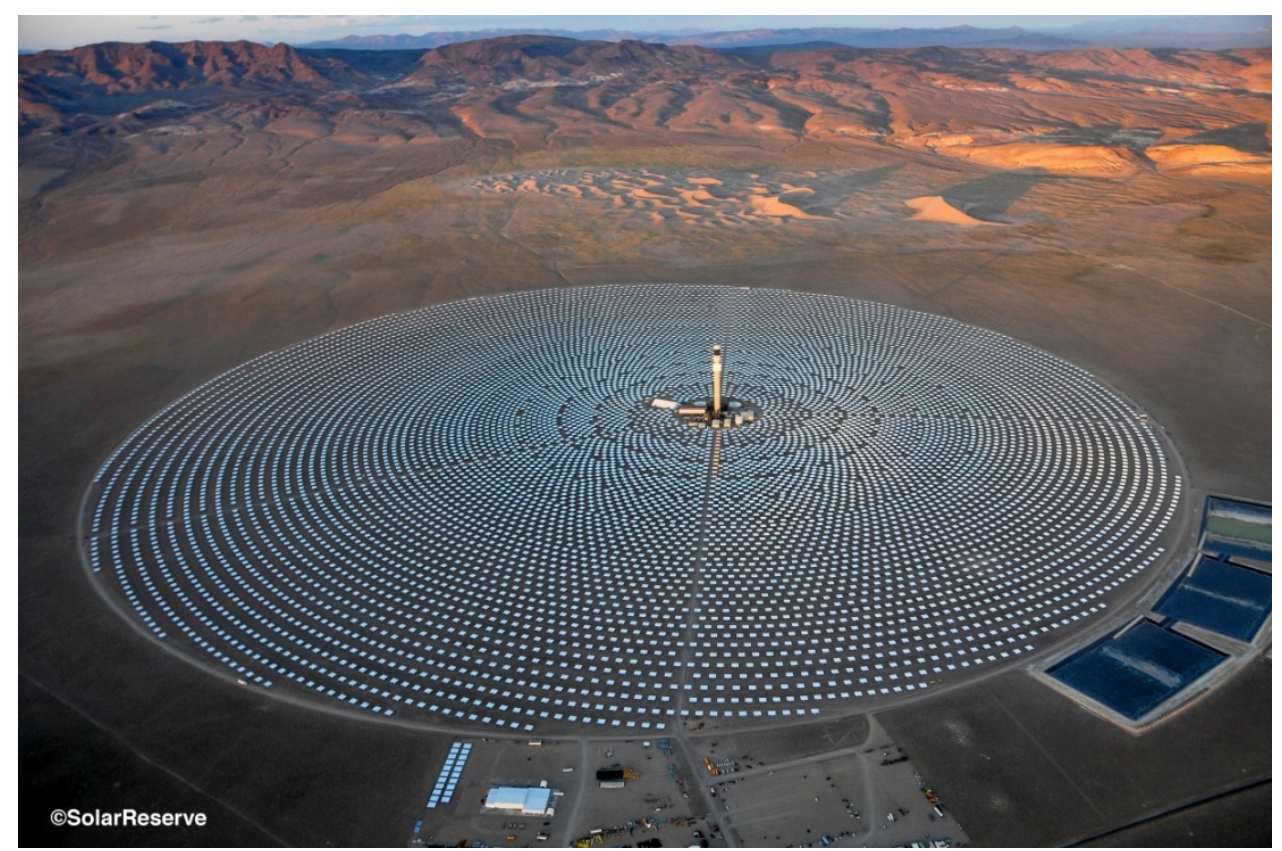

2 Figure 2: 110-MWe Crescent Dunes tower CSP plant in Tonopah, Nevada, USA, with 10 hours of thermal storage in $\sim 32000$ tons Solar Salt. (source: SolarReserve)

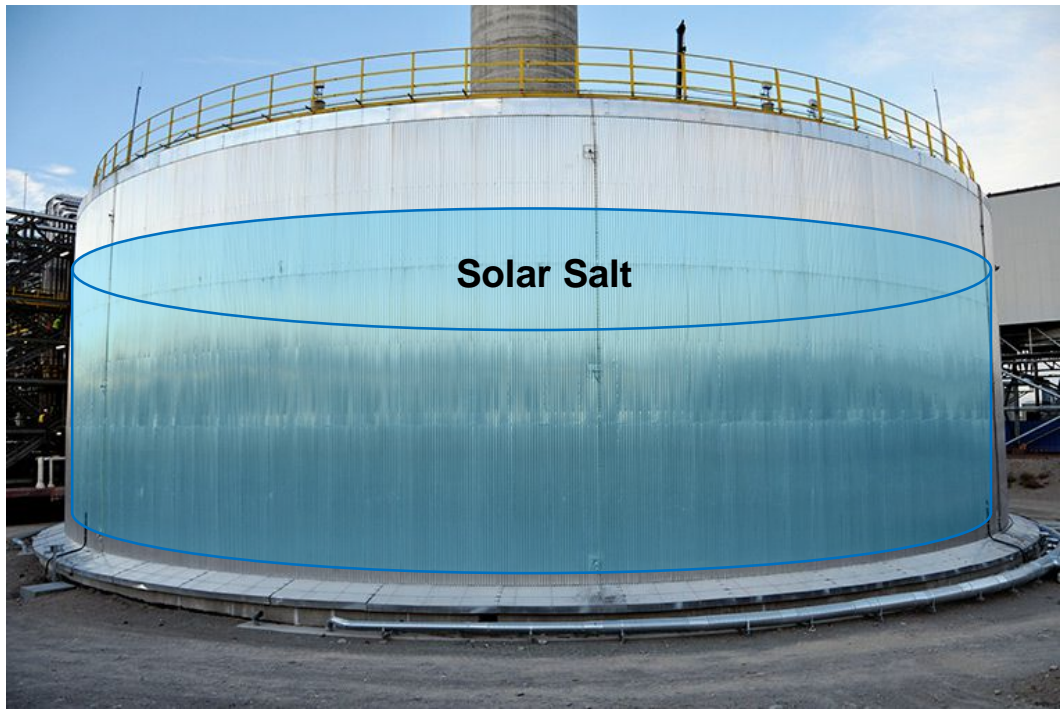

5 Figure 3: A molten salt storage tank (container) for the Crescent Dunes solar power plant. Size of tank:

612.2 meters tall and 42.7 meters in diameter. Storage capacity: 32000 tons molten salt. (source:

7 SolarReserve)

8 However, as Solar Salt decomposes at temperatures around $550^{\circ} \mathrm{C}[7,8]$, the temperature 9 difference (or heat storage capacity) defined by the hot and cold salt temperature is limited. 10 More importantly, it would be attractive to raise the upper operation temperature to $>550{ }^{\circ} \mathrm{C}$ in order to increase the efficiency of the power cycle. Table 1 compares the thermophysical properties and large-scale prices of commonly considered molten salts as TES and HTF materials in CSP. From the comparison, it can be concluded that: 
- Commercial nitrate/nitrite salts have high heat capacities and low prices, but low thermal stability limits (decomposed at $\sim 550^{\circ} \mathrm{C}$ ).

- Carbonate salts have high thermal stability limits (stable $>650^{\circ} \mathrm{C}$ ) and high heat capacities, but high prices particularly when containing expensive $\mathrm{Li}_{2} \mathrm{CO}_{3}$.

- Fluoride salts have high thermal stability limits (stable $>700^{\circ} \mathrm{C}$ ) and high heat capacities, but are toxic and expensive.

- Chloride salts have high thermal stability limits (stable $>800^{\circ} \mathrm{C}$ ), moderate heat capacities, and low prices.

Table 1: Properties and prices of commonly used molten salts as TES/HTF in CSP $[4,7-10]$.

\begin{tabular}{|c|c|c|c|c|c|}
\hline $\begin{array}{l}\text { Molten salts } \\
\text { composition } \\
\text { (wt. \%) }\end{array}$ & $\begin{array}{c}\text { Melting } \\
\text { point }\left({ }^{\circ} \mathrm{C}\right)\end{array}$ & $\begin{array}{l}\text { Stability } \\
\text { limit }\left({ }^{\circ} \mathrm{C}\right)\end{array}$ & $\begin{array}{l}\text { Density } \\
\left(\mathrm{g} \mathrm{cm}^{-3}\right)\end{array}$ & $\begin{array}{c}\text { Heat } \\
\text { capacity } \\
\left(\mathrm{KJ} \mathrm{kg}^{-1} \mathrm{~K}^{-1}\right)\end{array}$ & $\begin{array}{c}\text { Material } \\
\text { Cost } \\
\text { (US \$/kg) }\end{array}$ \\
\hline Solar Salt & $240[8]$ & $530-565$ [8] & $\sim 1.8[8]$ & $\sim 1.5[8]$ & $0.8[4]$ \\
\hline $\begin{array}{c}\mathrm{KNO}_{3} / \mathrm{nANO}_{3} \\
(40 / 60)\end{array}$ & & & $\left(400^{\circ} \mathrm{C}\right)$ & $\left(400^{\circ} \mathrm{C}\right)$ & 0.5 [7] \\
\hline $\begin{array}{c}\text { Hitec } \\
\mathrm{KNO}_{3} / \mathrm{NaNO}_{3} / \mathrm{NaNO}_{2} \\
(53 / 7 / 40)\end{array}$ & 142 [8] & $450-540$ [8] & $\begin{array}{l}\sim 1.8[8] \\
\left(400^{\circ} \mathrm{C}\right)\end{array}$ & $\begin{array}{c}1.5[8] \\
\left(400^{\circ} \mathrm{C}\right)\end{array}$ & 0.9 [7] \\
\hline $\begin{array}{c}\text { LiNaK carbonates } \\
\mathrm{K}_{2} \mathrm{CO}_{3} / \mathrm{Li}_{2} \mathrm{CO}_{3} / \mathrm{Na}_{2} \mathrm{CO}_{3} \\
(32 / 35 / 33)\end{array}$ & 397 [8] & $>650$ [8] & $\begin{array}{c}2.0[8] \\
\left(700^{\circ} \mathrm{C}\right)\end{array}$ & $\begin{array}{c}1.9[8] \\
\left(700^{\circ} \mathrm{C}\right)\end{array}$ & $\begin{array}{c}2.5[4] \\
\sim 1.3[7]\end{array}$ \\
\hline $\begin{array}{l}\text { LiNaK fluorides } \\
\text { KF/LiF/NaF } \\
(59 / 29 / 12)\end{array}$ & 454 [8] & $>700$ [8] & $\begin{array}{c}2.0[8] \\
\left(700^{\circ} \mathrm{C}\right)\end{array}$ & $\begin{array}{c}1.9[8] \\
\left(700^{\circ} \mathrm{C}\right)\end{array}$ & $>2^{*}$ \\
\hline $\begin{array}{c}\text { ZnNaK chlorides } \\
\mathrm{KCl} / \mathrm{NaCl} / \mathrm{ZnCl}_{2} \\
(23.9 / 7.5 / 68.6)\end{array}$ & 204 [7] & 850 [7] & $\begin{array}{l}\sim 2.0[9] \\
\left(600^{\circ} \mathrm{C}\right)\end{array}$ & $\begin{array}{c}0.8[7] \\
\left(300-600^{\circ} \mathrm{C}\right)\end{array}$ & $\begin{array}{l}0.8[4] \\
<1[7]\end{array}$ \\
\hline $\begin{array}{l}\text { MgNaK chlorides } \\
\mathrm{KCl} / \mathrm{MgCl}_{2} / \mathrm{NaCl} \\
(17.8 / 68.2 / 14.0)\end{array}$ & 380 [10] & $>800$ [4] & $\begin{array}{l}\sim 1.7[9] \\
\left(600^{\circ} \mathrm{C}\right)\end{array}$ & $\begin{array}{c}\sim 1.0[9] \\
\left(500-800^{\circ} \mathrm{C}\right)\end{array}$ & $<0.35$ [4] \\
\hline
\end{tabular}

Regarding the thermophysical properties and large-scale prices, chloride salts containing $\mathrm{MgCl}_{2}$ or $\mathrm{ZnCl}_{2}$ have been identified to be one of the most promising TES and HTF materials in the next generation CSP defined by U.S. Department of Energy (DOE), combining the supercritical carbon dioxide $\left(\mathrm{sCO}_{2}\right)$ Brayton cycle $\left(\mathrm{T}>720^{\circ} \mathrm{C}\right)$ for increasing thermo-electric conversion efficiency (see Figure 4) [4]. However, the high operating temperature of chloride salt mixtures causes additional challenges, particularly increase corrosiveness of structural 
alloys in the containers and tubes [4, 11, 12]. Addition of $\mathrm{MgCl}_{2}$ or $\mathrm{ZnCl}_{2}$ in chloride salt mixtures leads to low melting points. However, $\mathrm{MgCl}_{2}$ and $\mathrm{ZnCl}_{2}$ are strongly hydrophilic chlorides. A small amount of inherent water leads to a severe corrosion of alloys in the molten chlorides [4, 11]. Thus, studies on decomposition and purification of hydrophilic chlorides, and on corrosion behaviors and mechanisms of alloys in molten chlorides at high operating temperatures $\left(500-800^{\circ} \mathrm{C}\right)$, are essential to realize the applications of molten chlorides in CSP and high-temperature industrial processes [1, 4].

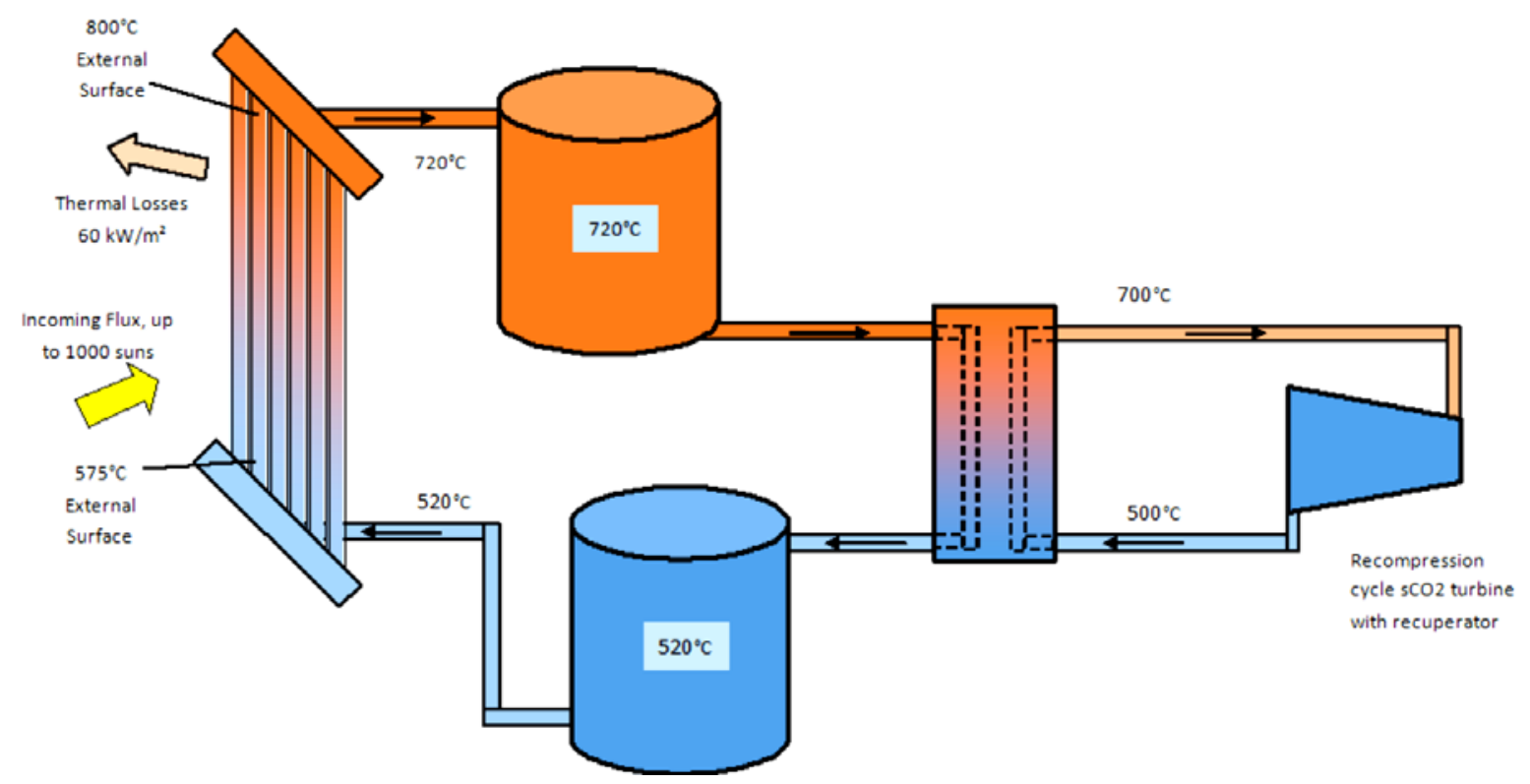

Figure 4: High temperature molten salt loop schematic with potential surface and fluid temperatures [4]. Adapted from Concentrating Solar Power Gen3 Demonstration Roadmap of NREL, USA.

Reviews on corrosion of metallic alloys in molten salts at high temperatures have been published in several books, e.g., in molten nitrates/nitrites, carbonates, sulphates $[13,14]$ and molten chlorides [14]. Moreover, to assist the corrosion control, the use of electrochemical techniques such as polarization curves was introduced to study and monitor steel corrosion in molten salts [13]. Currently, Patel et al. [15] reviewed the results of recent studies on compatibility of molten salts (fluorides, nitrates, chlorides, sulphates, carbonates) with the structural alloys and materials. Emphasis of this review [15] was also given on corrosion kinetics of the structural alloys and materials in these molten salts with focus on reaction mechanisms and corrosion products. However, all the publications above did not give in-depth insight into the effect of corrosive impurities in molten chloride salts and atmosphere over molten chloride salts on the corrosion rates of alloys. To our best knowledge, a review focusing on corrosion studies of alloys in molten chlorides is also not available. 
Corrosion of metallic alloys in molten chlorides consists of: 1). interaction of chloride melts with covering gases (i.e., atmosphere), 2). reactions in chloride melts and 3). interaction of metallic alloys with chloride melts. Thus, the first part of this review discusses the interaction of chloride melts with covering gases (Chapter 2). Then, decomposition and purification of chloride salts with hydrated water (impurities production during heating and its suppression), as well as a novel electrochemical technique developed by DLR to in-situ monitor corrosive impurities remaining in molten chlorides are introduced in Chapter 3. Finally, Chapter 4 reviews corrosion rates and mechanisms of various alloys in molten chlorides under various conditions, as well as a brief introduction of corrosion mitigation methods available in literature.

\section{Interaction of chloride melts with gases}

In the molten salt storage tanks for TES, the molten salts are covered with a covering gas for salt stabilization (e.g., air for nitrates/nitrites, $\mathrm{CO}_{2}$ containing gases for carbonates), or to avoid intake of corrosive gases such as $\mathrm{O}_{2}$ and water vapor from the atmosphere (e.g., inert gases like argon for chlorides).

Table 2 summarizes the solubilities of gases $\mathrm{O}_{2}, \mathrm{H}_{2} \mathrm{O}, \mathrm{HCl}, \mathrm{Cl}_{2}$ and $\mathrm{CO}_{2}$ in molten chlorides $\left(\mathrm{H}_{2}\right.$ in molten fluorides) and their interaction with molten chlorides. The gases $\mathrm{O}_{2}, \mathrm{H}_{2} \mathrm{O}, \mathrm{HCl}$, $\mathrm{Cl}_{2}, \mathrm{CO}_{2}$ and $\mathrm{H}_{2}$ possess a low solubility in molten alkali and alkaline-earth chlorides/ fluorides $[12,16]$. At $850-925^{\circ} \mathrm{C}$, the solubility constants (i.e., Henry's law constant) of $\mathrm{H}_{2} \mathrm{O}$, $\mathrm{HCl}, \mathrm{Cl}_{2}$ and $\mathrm{CO}_{2}$ in single chlorides or chloride mixtures are in the range of $10^{-7}$ to $10^{-5} \mathrm{~mol}$ $\mathrm{cm}^{-3}$ atm, while $\mathrm{O}_{2}$ has an even smaller solubility constant of $\sim 10^{-8} \mathrm{~mol} \mathrm{~cm}^{-3}$ atm [12]. The solubility constant of $\mathrm{H}_{2}$ in molten $\mathrm{LiF}_{-}-\mathrm{BeF}_{2}(66-34 \mathrm{~mol} \%)$ at $600^{\circ} \mathrm{C}$ is $4.3 \times 10^{-8} \mathrm{~mol} \mathrm{~cm}{ }^{-3}$ atm [16].

In spite of low solubilities, the oxidizing gases $\mathrm{O}_{2}$ and $\mathrm{H}_{2} \mathrm{O}$ dissolved in molten chlorides cause a significant metal corrosion even if the metal has no direct contact with the gases [12]. As shown in Table 2 and reactions (1-2), the oxygen gas $[12,17]$ and water vapor $[4,11,18]$ can react with the molten chlorides to form $\mathrm{Cl}_{2}$ and $\mathrm{HCl}$.

$$
\begin{aligned}
& \text { Chlorination: } 4 \mathrm{Cl}^{-}(\mathrm{I})+\mathrm{O}_{2}(\mathrm{~g}) \rightarrow 2 \mathrm{Cl}_{2}(\mathrm{~g})+2 \mathrm{O}^{2-}(\mathrm{I}) \\
& \text { Hydrolysis: } \mathrm{H}_{2} \mathrm{O}(\mathrm{g})+\mathrm{Cl}^{-}(\mathrm{l}) \rightarrow \mathrm{HCl}(\mathrm{g})+\mathrm{OH}^{-}(\mathrm{l})
\end{aligned}
$$

Although the equilibrium constant of reaction (1) at $700-900^{\circ} \mathrm{C}$ is $10^{-25}-10^{-29}$ and the concentrations of $\mathrm{Cl}_{2}$ and of $\mathrm{O}^{2-}$ in the melts have to be very low [12], the chlorination reaction can be enhanced, if such cations as $\mathrm{Zn}^{2+}, \mathrm{Mg}^{2+}, \mathrm{Al}^{3+}, \mathrm{Fe}^{2+}, \mathrm{Cr}^{2+}, \mathrm{Ni}^{2+}$, etc., which can form low-solubility oxides with oxygen ions $[12,17]$, are present in the melts. Moreover, if 
1 these cations can form stable metal-hydroxyl ions (e.g., $\mathrm{MgOH}^{+}$) in the melts with hydroxyl 2 ions [11, 18], the hydrolysis reaction (reaction (2)) can be shifted to the right side. The 3 reaction products $\mathrm{Cl}_{2}$ and $\mathrm{HCl}$ as well as metal-hydroxyl ions have higher solubilities than $\mathrm{O}_{2}$ 4 in molten chlorides, which leads to an enhanced metal corrosion even if the metal has no 5 direct contact with the gases. Thus, in order to control corrosion of alloys in molten chlorides 6 for a long lifetime of CSP, the intake of $\mathrm{O}_{2}$ and $\mathrm{H}_{2} \mathrm{O}$ from the atmosphere and presence of $\mathrm{O}_{2}$ 7 and $\mathrm{H}_{2} \mathrm{O}$ in the covering gases should be avoided. Moreover, the chloride salts with 8 adsorbed $\mathrm{O}_{2}$ and $\mathrm{H}_{2} \mathrm{O}$ should be purified. 
Table 2. Gas solubilities in molten halides and gas interaction with pure molten chlorides.

\begin{tabular}{|c|c|c|c|c|c|c|}
\hline Gases & $\mathrm{O}_{2}$ & $\mathrm{H}_{2} \mathrm{O}$ & $\mathrm{HCl}$ & $\mathrm{Cl}_{2}$ & $\mathrm{CO}_{2}$ & $\mathbf{H}_{2}$ \\
\hline $\begin{array}{l}\text { Henry's law constant } \\
\left(\mathrm{mol} \mathrm{cm} \mathrm{cm}^{-3} \mathrm{~atm}\right)\end{array}$ & $\begin{array}{l}\sim 10^{-8} \\
\text { (chlorides) [12] }\end{array}$ & $\begin{array}{l}9.5 \times 10^{-6} \\
\left(\mathrm{NaCl}, 900^{\circ} \mathrm{C}\right)[16] \\
1.1 \times 10^{-5} \\
\left(\mathrm{KCl}, 900^{\circ} \mathrm{C}\right)[16]\end{array}$ & $\begin{array}{l}1.3 \times 10^{-6} \\
\left(\mathrm{NaCl}, 907^{\circ} \mathrm{C}\right)[16] \\
2.5 \times 10^{-6} \\
\left(\mathrm{KCl}, 907^{\circ} \mathrm{C}\right)[16] \\
8.4 \times 10^{-7} \\
\left(\mathrm{MgCl}_{2}, 904^{\circ} \mathrm{C}\right)[16] \\
2.0 \times 10^{-6} \\
\left(\mathrm{MgCl}_{2} / \mathrm{KCl}, 50 / 50\right. \\
\left.\mathrm{mol}^{2}, 875^{\circ} \mathrm{C}\right)[16]\end{array}$ & $\begin{array}{l}5.4 \times 10^{-7} \\
\left(\mathrm{NaCl}, 900^{\circ} \mathrm{C}\right)[16] \\
1.9 \times 10^{-6} \\
\left(\mathrm{KCl}, 900^{\circ} \mathrm{C}\right)[16] \\
7.3 \times 10^{-7} \\
\left(\mathrm{MgCl}_{2}, 925^{\circ} \mathrm{C}\right)[16] \\
3.4 \times 10^{-7} \\
\left(\mathrm{MgCl}_{2} / \mathrm{NaCl} / \mathrm{KCl},\right. \\
50 / 27.7 / 23.3 \mathrm{wt} \%, \\
\left.903^{\circ} \mathrm{C}\right)[16]\end{array}$ & $\begin{array}{l}6.19 \times 10^{-7} \\
\left(\mathrm{NaCl}, 904^{\circ} \mathrm{C}\right)[16] \\
7.9 \times 10^{-7} \\
\left(\mathrm{KCl}, 903^{\circ} \mathrm{C}\right)[16] \\
3.6 \times 10^{-6} \\
\left(\mathrm{MgCl}_{2}, 850^{\circ} \mathrm{C}\right)[16]\end{array}$ & 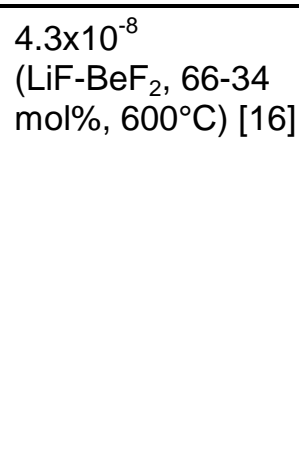 \\
\hline Interaction & $\begin{array}{l}\text { Yes }[12,17] \\
\text { Chlorination } \\
4 \mathrm{Cl}^{-}(\mathrm{I})+\mathrm{O}_{2}(\mathrm{I}, \mathrm{g}) \rightarrow \\
2 \mathrm{Cl}_{2}(\mathrm{l}, \mathrm{g})+2 \mathrm{O}^{2-}(\mathrm{I})\end{array}$ & $\begin{array}{l}\text { Yes }[11,18] \\
\text { Hydrolysis } \\
\mathrm{H}_{2} \mathrm{O}(\mathrm{l}, \mathrm{g})+\mathrm{Cl}^{-}(\mathrm{l}) \rightarrow \\
\mathrm{HCl}(\mathrm{l}, \mathrm{g})+\mathrm{OH}^{-}(\mathrm{l})\end{array}$ & N/A & $N / A$ & $\mathrm{~N} / \mathrm{A}$ & N/A \\
\hline
\end{tabular}




\section{Impurities in chloride melts}

\subsection{Decomposition and purification of hydrophilic chlorides}

Effort to reduce corrosiveness of the molten chloride salts with hydrophilic chlorides has been made to reduce the corrosive impurities by suppressing the side reactions of hydrolysis during the salt heating [18-20]. In this review, the decomposition and purification of $\mathrm{MgCl}_{2}$ is discussed as an example to understand the decomposition and purification of chlorides.

Maksoud et al. [18] have investigated the purification of a $\mathrm{MgCl}_{2}-\mathrm{NaCl}-\mathrm{KCl}$ salt mixture (6020-20 mole $\%$, melting temperature of $\left.\sim 400^{\circ} \mathrm{C}\right)$ containing hydrated $\mathrm{MgCl}_{2}\left(\mathrm{MgCl}_{2} \cdot 6 \mathrm{H}_{2} \mathrm{O}\right)$ via thermal analysis (differential scanning calorimetry (DSC)/thermogravimetric analysis (TGA)) coupled to mass spectrometry (MS), salt analysis (X-ray diffraction (XRD)) and monitoring produced $\mathrm{HCl}$ gas ( $\mathrm{PH}$-value analysis of the wash water with a $\mathrm{PH}$ electrode). In their work, an advanced process technology and purification approach (i.e., sweeping the salt with inert gas during the heating and keeping the temperature at $350^{\circ} \mathrm{C}$ before heating above the melting point until the salt is completely dehydrated) has been developed yielding improved salt quality with less impurities like corrosive $\mathrm{MgOHCl}$ and $\mathrm{HCl}$ and thus reduce corrosiveness [18].

Kipouros et al. [19] used multi-step heating to purify the hydrated $\mathrm{MgCl}_{2}$ according to a vapor pressure diagram of $\mathrm{H}_{2} \mathrm{O}$ and $\mathrm{HCl}$ over the hydrates of $\mathrm{MgCl}_{2}$ (see Figure 5). As shown in Figure 5, with the temperature increasing, the hydrophilic $\mathrm{MgCl}_{2}$ at room temperature $\mathrm{MgCl}_{2} \cdot 6 \mathrm{H}_{2} \mathrm{O}$ was dehydrated to $\mathrm{MgCl}_{2} \cdot 4 \mathrm{H}_{2} \mathrm{O}$ at $\mathrm{T}_{1}$, to $\mathrm{MgCl}_{2} \cdot 2 \mathrm{H}_{2} \mathrm{O}$ at $\mathrm{T}_{2}$ and to $\mathrm{MgCl}_{2} \cdot \mathrm{H}_{2} \mathrm{O}$ at $\mathrm{T}_{3}$, sequentially [19]. In order to reduce the side reaction of $\mathrm{MgCl}_{2} \cdot 2 \mathrm{H}_{2} \mathrm{O}$ to $\mathrm{MgOHCl}$ and $\mathrm{HCl}$ (see reaction (3)) and release more water vapor, the temperature was controlled between $\mathrm{T}_{3}$ and $\mathrm{T}_{4}$, until all the $\mathrm{MgCl}_{2} \cdot 2 \mathrm{H}_{2} \mathrm{O}$ is dehydrated to $\mathrm{MgCl}_{2} \cdot \mathrm{H}_{2} \mathrm{O}$ [19]. At the temperature higher than $\mathrm{T}_{4}$, the side reactions of $\mathrm{MgCl}_{2} \cdot \mathrm{H}_{2} \mathrm{O}$ and $\mathrm{MgCl}_{2} \cdot 2 \mathrm{H}_{2} \mathrm{O}$ to $\mathrm{MgOHCl}$ and $\mathrm{HCl}$ (see reactions (3) and (4)) can take place before the target reaction of $\mathrm{MgCl}_{2} \cdot \mathrm{H}_{2} \mathrm{O}$ to $\mathrm{MgCl}_{2}$ at $\mathrm{T}_{5}$ [19]. These side reactions were averted by increasing the partial pressure of $\mathrm{HCl}$ in the gas around the salt, e.g., by sweeping the salt with $\mathrm{HCl}$ [19].

$$
\begin{gathered}
\mathrm{MgCl}_{2} \cdot 2 \mathrm{H}_{2} \mathrm{O} \rightarrow \mathrm{MgOHCl}+\mathrm{HCl}+\mathrm{H}_{2} \mathrm{O} \\
\mathrm{MgCl}_{2} \cdot \mathrm{H}_{2} \mathrm{O} \rightarrow \mathrm{MgOHCl}+\mathrm{HCl} .
\end{gathered}
$$

However, even after salt purifications [18-20], still a small amount of hydroxide impurities remains in the salts. The formed $\mathrm{MgOHCl}$ can be dissolved in the molten chlorides (to $\mathrm{MgOH}^{+}$and $\mathrm{Cl}^{-}$) and decomposes further to $\mathrm{MgO}$ and corrosive $\mathrm{HCl}$ at high temperatures $\left(>555^{\circ} \mathrm{C}\right)$ [19]. Thus, metal-hydroxyl chloride salts such as $\mathrm{MgOHCl}$ are considered to be the 
most critical corrosive impurities in molten chlorides containing hydrophilic chlorides under inert atmosphere.

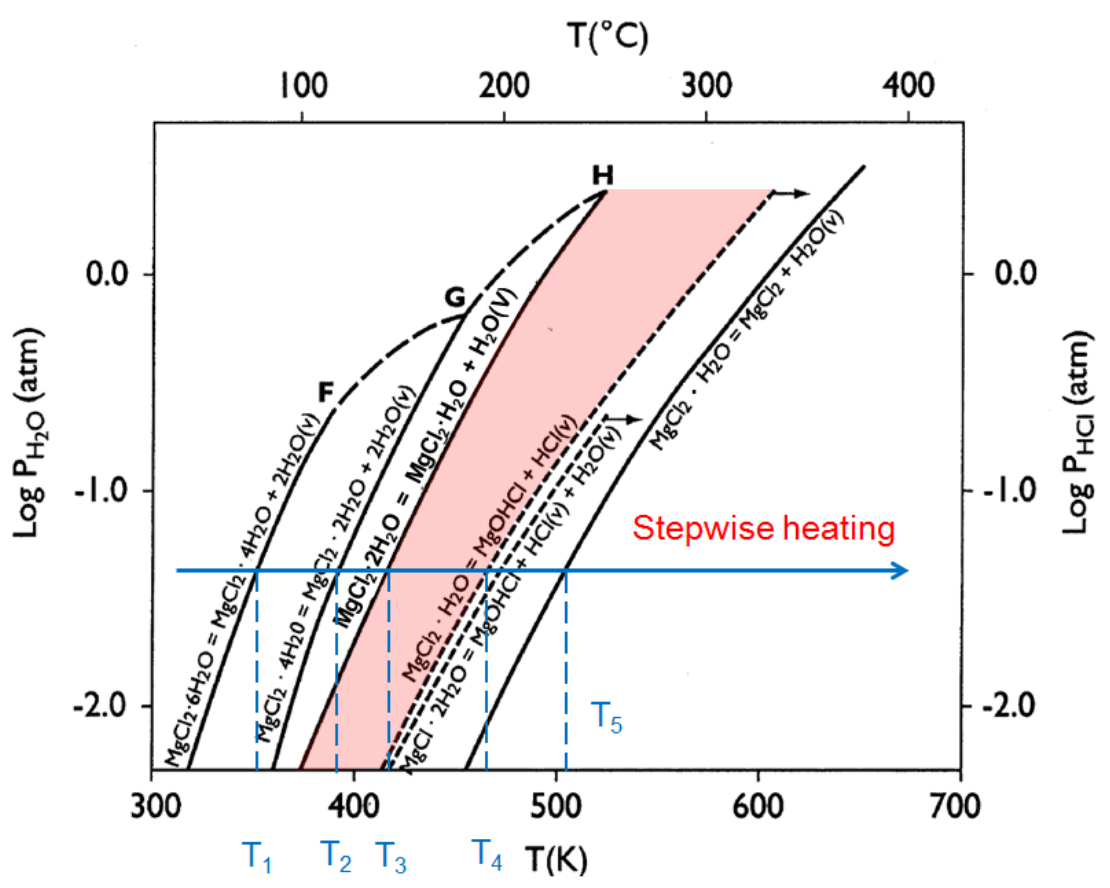

Figure 5: Vapor pressure of $\mathrm{H}_{2} \mathrm{O}$ and $\mathrm{HCl}$ over the hydrates of $\mathrm{MgCl}_{2}$ [19].

\subsection{Cyclic voltammetry to in-situ monitor corrosive impurities}

Cyclic voltammetry (CV) has been used to analyze the electrochemistry of molten chlorides, e.g., $\mathrm{MgCl}_{2} / \mathrm{NaCl}\left(730-850^{\circ} \mathrm{C}\right)$ for measuring hydroxide/oxide impurities [21], or $\mathrm{LiCl} / \mathrm{KCl} / \mathrm{TiCl}_{2}$ $\left(430-500^{\circ} \mathrm{C}\right)$ for the synthesis of Ti alloys [22]. For an efficient control of corrosive impurity concentrations in molten chloride salts, earlier studies conducted by the authors of this review [23-25] used CV to in-situ measure the corrosive impurities in molten chlorides, e.g., hydroxide containing ion $\mathrm{MgOH}^{+}$in molten $\mathrm{NaCl}-\mathrm{KCl}-\mathrm{MgCl}_{2}$. Compared to the ex-situ methods such as titration [21, 24], generally via collecting and analyzing a salt sample out of the melt, in-situ measurements of the impurities such as hydroxide containing ions with an electrochemical analytic system based on cyclic voltammetry (CV) provide unique possibility to monitor impurity concentrations and thus control the technological processes [21, 24].

It was found that in melts such as $\mathrm{MgCl}_{2}-\mathrm{NaCl}$ [21], $\mathrm{NaCl}-\mathrm{KCl}$ [26], $\mathrm{MgCl}_{2}-\mathrm{KCl}$ [26], $\mathrm{LiCl}-\mathrm{KCl}$ [26], $\mathrm{CaCl}_{2}-\mathrm{CaO}$ [27], $\mathrm{CaCl}_{2}-\mathrm{KCl}$ [28], the heights of the reduction peaks of hydroxide/oxide species in cyclic voltammograms (CVG) were directly proportional to the concentrations of hydroxide/oxide species. This phenomenon was also observed by the CV experiments in our studies [23-25] for the concentration of $\mathrm{MgOH}^{+}$corrosive impurity in molten $\mathrm{NaCl}-\mathrm{KCl}-\mathrm{MgCl}_{2}$ $\left(60 / 20 / 20\right.$ mole\%) salts at temperatures of $500-700^{\circ} \mathrm{C}$. A typical cyclic voltammogram by 
using the tungsten working electrode [24] is shown in Figure 6. The peak B was considered to represent the following electrochemical reaction [24]:

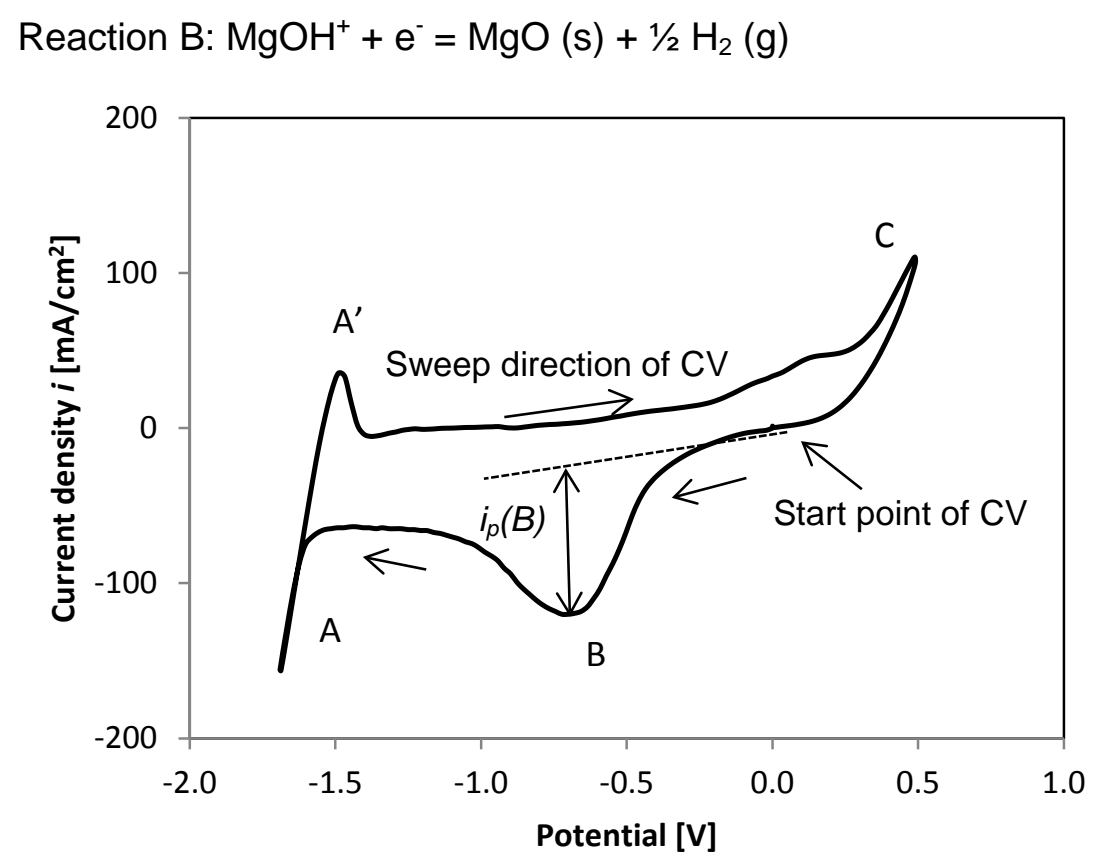

Figure 6: Cyclic voltammogram in $\mathrm{MgCl}_{2} / \mathrm{KCl} / \mathrm{NaCl}$ at $500^{\circ} \mathrm{C}$ obtained by a tungsten working electrode. Sweep rate: $200 \mathrm{mV} / \mathrm{s}$. Tungsten reference electrode. $i_{p}(B)$ : peak current density for reaction $\mathrm{B}$. Adopted from [24].

By fitting the CV data with those from the acid consumption measurements (i.e., titration) on the simultaneously collected salt samples, it was found that the peak current density of the peak $\mathrm{B}\left(i_{p}(B)\right)$ was proportional to the bulk concentration of $\left.\mathrm{MgOH}^{+}\left(c^{\infty}\left(\mathrm{MgOH}^{+}\right)\right)\right)$in the studied temperature range, i.e., at $500-700{ }^{\circ} \mathrm{C}$ [23-25]:

$$
i_{p}(B)=k(T, v)(B) \cdot c^{\infty}\left(M g O H^{+}\right),
$$

where $i_{p}$ represents the peak current density in $\mathrm{mA} / \mathrm{cm}^{2} ; k(T, v)$ is a constant, i.e., the slope of peak current densities vs. concentrations of the reacting species in $(\mathrm{ppm} O) /\left(\mathrm{mA} / \mathrm{cm}^{2}\right)$, which depends on the temperature $T$ and $v$ potential sweep rate; $C^{\infty}$ is the bulk concentration of the reacting species in ppm O. As shown in Figure 7 from [25], the slope rates of current densities vs. concentrations of $\mathrm{MgOH}^{+}$at $500-700^{\circ} \mathrm{C}$ were determined, which compare well with literature [21]. Thus, the peak current densities of the peak B obtained via $\mathrm{CV}$ could simply be used to in-situ monitor the concentration of the hydroxide impurity in the molten $\mathrm{NaCl}-\mathrm{KCl}-\mathrm{MgCl}_{2}$ [25]. This method may be extended to other molten chloride salts with hydroxide impurity or other impurities. 

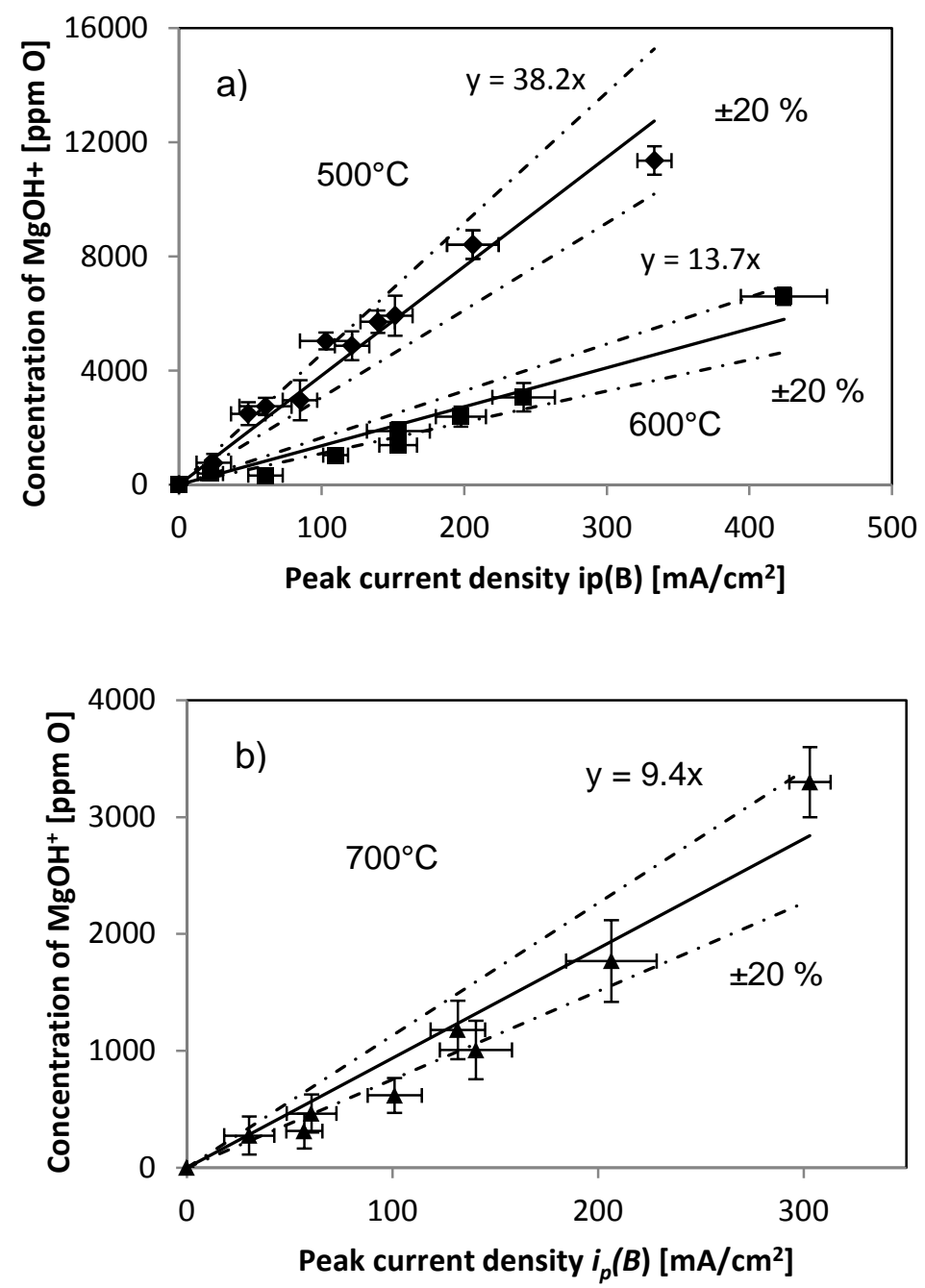

Figure 7: Peak current densities vs. concentrations of corrosive $\mathrm{MgOH}^{+}$in molten $\mathrm{MgCl}_{2} / \mathrm{KCl} / \mathrm{NaCl}$ $(60 / 20 / 20 \mathrm{~mole} \%)$ at a) $500,600^{\circ} \mathrm{C}$ and b) $700^{\circ} \mathrm{C}$. Error bars represent the standard deviations in the $\mathrm{CV}$ (three measurements) and AC measurements (three measurements). Adopted from [24].

\section{Corrosion of alloys in molten chlorides}

\subsection{Corrosion rates of alloys in molten chlorides}

As molten chlorides are promising TES and HTF materials in the next generation CSP regarding their thermal properties and prices [4], corrosion behaviors of alloys in them have been investigated intensively in the last years (e.g. starting with the work in the US SunShot Initiative). Table 3 summarizes the corrosion rates of various alloys (stainless steels, nickelbased superalloys, some model alloys) in molten chloride mixtures under various conditions (e.g., various temperatures, under oxidizing or inert atmosphere) [14, 29-35]. 
The corrosion rates $(C R)$ were conventionally determined with a mass loss measurement (referred to method "I+M") or microstructural analysis (referred to method "I+MS") on the exposed alloy specimens after immersion tests in the melts according to the following equations $[14,29]$ :

$$
\begin{gathered}
\text { method "I+M": } C R=\frac{\Delta m}{\rho \cdot A} \cdot \frac{365 \cdot 24}{t} \cdot 10^{4}, \\
\text { method "I+M": } C R=S_{\text {corr }} \cdot \frac{365 \cdot 24}{t},
\end{gathered}
$$

where $C R$ has the unit of $\mu \mathrm{m} / \mathrm{year} ; \Delta m$ is the mass change of the exposed alloy specimen after immersion test, $\mathrm{g} ; \rho$ is the density of the exposed alloy specimen, $\mathrm{g} \mathrm{cm}^{-3}$; $A$ is the contact area of the exposed alloy specimen with the melt, $\mathrm{cm}^{2} ; t$ is the immersion time, hour; $S_{c o r r}$ is the thickness of the corrosion layer of the exposed alloy specimen, $\mu \mathrm{m}$.

Besides these post-analysis methods (methods "I+M" and "I+MS"), the electrochemical techniques such as potentiodynamic polarization (PDP) [30-32, 34, 35] and electrochemical impedance spectroscopy (EIS) (for alloys in $\mathrm{KCl} / \mathrm{MgCl}_{2}$ at $550-700^{\circ} \mathrm{C}$ [36]) were used for insitu and fast measurements of the corrosion rates. The corrosion current obtained with the electrochemical techniques can be used to calculate an estimated corrosion rate according to Faraday law [14, 30-32]:

$$
C R=k\left[\left(I_{\text {corr }} \cdot E W\right) / \rho \cdot A\right],
$$

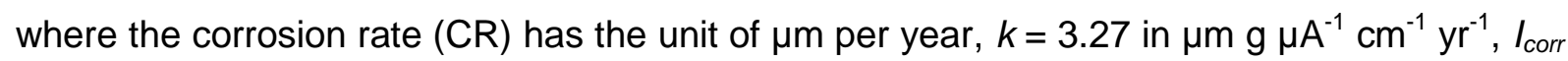
is the corrosion current in $\mu \mathrm{A}, \mathrm{A}$ is the contact area of the working electrode (studied alloys) with molten chlorides, $E W$ and $\rho$ are the equivalent weight (dimensionless) and density ( $\mathrm{g}$ $\mathrm{cm}^{-3}$ ) of the alloy sample, respectively [31].

Compared to the conventional immersion methods, which generally require several immersion days to detect the mass loss and microstructural change of the exposed alloy specimens, the electrochemical techniques can give indicative corrosion rates of alloys within several minutes. Thus, they can be used for parametric studies of corrosion rates of alloys. Compared to PDP and EIS, post analysis on the exposed alloy specimens after immersion tests can provide more information on the corrosion layers and mechanisms by analyzing the corrosion products and microstructures of the exposed alloys.

From Table 3, it can be concluded that the temperature of molten chlorides and the atmosphere (with or without oxidizing species) above the molten chlorides have significant effect on the corrosion of alloys in molten chlorides. The corrosion rates of alloys in molten chloride mixtures increase with increasing temperature, significantly, in particular above 
$600{ }^{\circ} \mathrm{C}$. For instance, the corrosion rate of $\mathrm{Ha} \mathrm{C}-276$ in molten $\mathrm{ZnCl}_{2}-\mathrm{NaCl}-\mathrm{KCl}$ under air increased more than 10-fold (from 40 to $500 \mu \mathrm{m} /$ year), when the temperature increased from 500 to $800{ }^{\circ} \mathrm{C}[31]$.

As oxidizing species $\mathrm{O}_{2}$ and $\mathrm{H}_{2} \mathrm{O}$ existing in air as covering gas can accelerate the corrosion of alloys. Alloys in molten chlorides have much higher corrosion rates under air atmosphere than under inert atmosphere, e.g., SS 304, $\mathrm{Ha} \mathrm{C}-22$ and $\mathrm{Ha} \mathrm{C}-276$ in molten $\mathrm{ZnCl} 2-\mathrm{NaCl}-\mathrm{KCl}$ [31]. However, severe corrosion occurred also in inert atmosphere, e.g. SS and Incoloy alloys in molten $\mathrm{NaCl}-\mathrm{KCl}$ under nitrogen atmosphere at $650-700^{\circ} \mathrm{C}$ [32], SS alloys in molten $\mathrm{KCl} / \mathrm{NaCl} / \mathrm{VCl}_{2}$ under argon atmosphere [34], if corrosive species such as $\mathrm{O}_{2}, \mathrm{H}_{2} \mathrm{O}, \mathrm{V}^{2+}$ exists in the melts. Moreover, it was concluded that molten chlorides were too aggressive to be used at $900{ }^{\circ} \mathrm{C}$ under the atmosphere with $\mathrm{O}_{2}$ and $\mathrm{H}_{2} \mathrm{O}$, and reducing these oxidizing impurities in molten chlorides can also significantly reduce the corrosiveness of the molten chlorides [14].

For the corrosion behavior of commercial alloys in molten nitrate salt mixtures such as Solar Salt it is well understood, that the corrosion resistance of alloys to molten nitrate salt mixtures improves with increasing nickel content [14]. From the available corrosion data in literature for alloys in molten chlorides summarized in Table 3, it can be concluded that nickel-based superalloys such as Incoloy, Inconel and Hastelloy, which have higher prices due to higher $\mathrm{Ni}$ contents, mostly have better corrosion resistance in molten chloride salts than stainless steels [32-33]. However, the conclusion that the resistance of alloys improves with increasing nickel content, is not always true for alloys to molten chlorides. In some cases, the alloys with higher Ni-content have worse corrosion resistance, e.g., Ha N ( 71\% nickel) has higher corrosion rates in molten $\mathrm{ZnCl}_{2}-\mathrm{NaCl}-\mathrm{KCl}$ than $\mathrm{Ha} \mathrm{C}-22$ ( $\sim 56 \%$ nickel) and $\mathrm{Ha} \mathrm{C}-276(\sim 57 \%$ nickel) at $250-500^{\circ} \mathrm{C}$ [30], also in $\mathrm{NaCl}-\mathrm{KCl}-\mathrm{MgCl}_{2}$ than SS 304 (8-11\% nickel) and SS 316 (10-14\% nickel) at $450-500^{\circ} \mathrm{C}$ [14]. Ha $\mathrm{N}$ has been found to be most suitable in molten fluoride salts after extensive studies for nuclear applications at temperatures of $>700^{\circ} \mathrm{C}$ under vacuum or an inert atmosphere [14]. However, other studies [14, 30] indicate that $\mathrm{Ha}$ $\mathrm{N}$ is not suitable for molten chloride salts under air or vacuum. 
Table 3: Results of corrosion studies metallic alloys in molten chlorides.

\begin{tabular}{|c|c|c|c|c|c|c|}
\hline Molten Salts (wt. \%) & Alloy (Ni wt.\%) & $\mathrm{T}\left({ }^{\circ} \mathrm{C}\right)$ & Atmosphere & Method & Corrosion rate ( $\mu$ m/year) & Ref \\
\hline $\mathrm{KCl} / \mathrm{NaCl} / \mathrm{ZnCl}{ }_{2}$ & $\mathrm{Ha} \mathrm{N}(\sim 71)$ & 250 & air & PDP & 37 & {$[30]$} \\
\hline \multirow[t]{17}{*}{$(24.0 / 7.4 / 68.6)$} & & 500 & air & PDP & 160 & {$[30]$} \\
\hline & $\mathrm{Ha} \mathrm{C}-22(\sim 56)$ & 250 & air & PDP & 16 & {$[30]$} \\
\hline & & 500 & air & PDP & 50 & [30] \\
\hline & $\mathrm{Ha} \mathrm{C-276} \mathrm{(} \mathrm{57)}$ & 250 & air & PDP & 11 & [30] \\
\hline & & 500 & air & PDP & 42 & {$[30]$} \\
\hline & SS $304(8-11)$ & 250 & air & PDP & 22 & [31] \\
\hline & & 500 & air & PDP & 381 & [31] \\
\hline & & 400 & absence of air & $\mathrm{I}+\mathrm{M}(1000 \mathrm{~h})$ & 14 & [31] \\
\hline & $\mathrm{Ha} \mathrm{C-22}(\sim 56)$ & 250 & air & PDP & 15 & [31] \\
\hline & & 500 & air & PDP & 42 & [31] \\
\hline & & 400 & absence of air & I+M (1000 h) & 8 & [31] \\
\hline & & 800 & absence of air & I+M (1000 h) & 14 & [31] \\
\hline & Ha C-276 $(\sim 57)$ & 500 & air & PDP & 40 & [31] \\
\hline & & 800 & air & PDP & 500 & [31] \\
\hline & & 400 & absence of air & $\mathrm{I}+\mathrm{M}(1000 \mathrm{~h})$ & 3 & [31] \\
\hline & & 800 & absence of air & I+M (1000 h) & 4 & [31] \\
\hline & & 500 & air & I+M (1000 h) & 80 & {$[31]$} \\
\hline $\mathrm{CaCl}_{2} / \mathrm{MgCl}_{2} / \mathrm{NaCl}$ & Inc $625(-62)$ & 600 & air & $\mathrm{I}+\mathrm{M}(504 \mathrm{~h})$ & 121 & {$[29]$} \\
\hline \multirow[t]{2}{*}{$(43.6 / 17.7 / 38.7)$} & $\mathrm{Ha} \times(\sim 47)$ & 600 & air & I+M (504 h) & 153 & [29] \\
\hline & На В-3 ( 65) & 600 & air & I+M (504 h) & 144 & [29] \\
\hline $\mathrm{KCl} / \mathrm{MgCl}_{2} / \mathrm{NaCl}$ & SS 304 (8-11) & $450-500$ & vacuum & $\mathrm{I}+\mathrm{M}(1000 \mathrm{~h})$ & $<10$ & {$[14]$} \\
\hline \multirow[t]{2}{*}{$(20.4 / 55.1 / 24.5)$} & SS $316(10-14)$ & $450-500$ & vacuum & I+M (1000 h) & $\sim 10$ & {$[14]$} \\
\hline & SS 347 (9-12) & $450-500$ & vacuum & I+M (1000 h) & $\sim 120$ & {$[14]$} \\
\hline
\end{tabular}




\begin{tabular}{|c|c|c|c|c|c|c|}
\hline & $\mathrm{Ha} N(\sim 71)$ & $450-500$ & vacuum & I+M (1000 h) & $\sim 50$ & [14] \\
\hline & SS 304 (8-11) & 900 & $\mathrm{~N}_{2}-\left(0.1-1 \% \mathrm{H}_{2} \mathrm{O}\right)-\left(1-10 \% \mathrm{O}_{2}\right)$ & I+M (144 h) & Disintegrated & [14] \\
\hline & SS 316 (10-14) & 900 & $\mathrm{~N}_{2}-\left(0.1-1 \% \mathrm{H}_{2} \mathrm{O}\right)-\left(1-10 \% \mathrm{O}_{2}\right)$ & I+M (144 h) & Disintegrated & [14] \\
\hline & In 800H (30-35) & 900 & $\mathrm{~N}_{2}-\left(0.1-1 \% \mathrm{H}_{2} \mathrm{O}\right)-\left(1-10 \% \mathrm{O}_{2}\right)$ & I+M (144 h) & 23725 & [14] \\
\hline & Ha $230(\sim 57)$ & 900 & $\mathrm{~N}_{2}-\left(0.1-1 \% \mathrm{H}_{2} \mathrm{O}\right)-\left(1-10 \% \mathrm{O}_{2}\right)$ & I+M (144 h) & 20345 & [14] \\
\hline $\mathrm{KCl} / \mathrm{NaCl} / \mathrm{VCl}_{2}$ & SS 316L (13.5-15.0) & 750 & Argon & I+M (6 h) & 54000 & [34] \\
\hline \multirow[t]{5}{*}{$(53.3 / 41.7 / 5.0)$} & & 750 & Argon & PDP (6 h) & 1600 & [34] \\
\hline & SS 316Ti (12-14) & 750 & Argon & I+M (6h) & 61000 & [34] \\
\hline & & 750 & Argon & PDP $(6 \mathrm{~h})$ & 7000 & [34] \\
\hline & SS 321 (9-11) & 750 & Argon & I+M (6h) & 22200 & [34] \\
\hline & & 750 & Argon & PDP $(6 \mathrm{~h})$ & 15100 & [34] \\
\hline $\mathrm{KCl} / \mathrm{NaCl}$ & SS 316L (13.5-15.0) & 750 & Argon & $\mathrm{I}+\mathrm{M}(80 \mathrm{~h})$ & $\sim 157$ & [35] \\
\hline \multirow[t]{2}{*}{$(56.1 / 43.9)$} & SS 316Ti (12-14) & 750 & Argon & I+M (80 h) & $\sim 168$ & [35] \\
\hline & SS $321(9-11)$ & 750 & Argon & $\mathrm{I}+\mathrm{M}(80 \mathrm{~h})$ & $\sim 225$ & [35] \\
\hline $\mathrm{KCl} / \mathrm{LiCl}$ & SS 304 (8-11) & 400 & absence of air & $\mathrm{I}+\mathrm{M}(\mathrm{N} / \mathrm{A})$ & 2 & [14] \\
\hline \multirow[t]{3}{*}{$(55.8 / 44.2)$} & & 500 & absence of air & $\mathrm{I}+\mathrm{M}(\mathrm{N} / \mathrm{A})$ & 6 & [14] \\
\hline & SS 316 (10-14) & 400 & absence of air & $\mathrm{I}+\mathrm{M}(\mathrm{N} / \mathrm{A})$ & 2 & [14] \\
\hline & SS 347 (9-12) & 500 & absence of air & $\mathrm{I}+\mathrm{M}(\mathrm{N} / \mathrm{A})$ & 2 & [14] \\
\hline $\mathrm{LiCl} / \mathrm{NaCl}$ & SS 347 (9-12) & 650 & nitrogen & PDP & 7490 & [32] \\
\hline \multirow[t]{5}{*}{$(68.6 / 34.4)$} & SS $310(\sim 20.5)$ & 650 & nitrogen & PDP & 6420 & [32] \\
\hline & & 700 & nitrogen & PDP & 12450 & [32] \\
\hline & In $800 \mathrm{H}(30-35)$ & 650 & nitrogen & PDP & 5940 & [32] \\
\hline & & 700 & nitrogen & PDP & 14310 & [32] \\
\hline & Inc $625(\sim 62)$ & 650 & nitrogen & PDP & 2800 & [32] \\
\hline
\end{tabular}




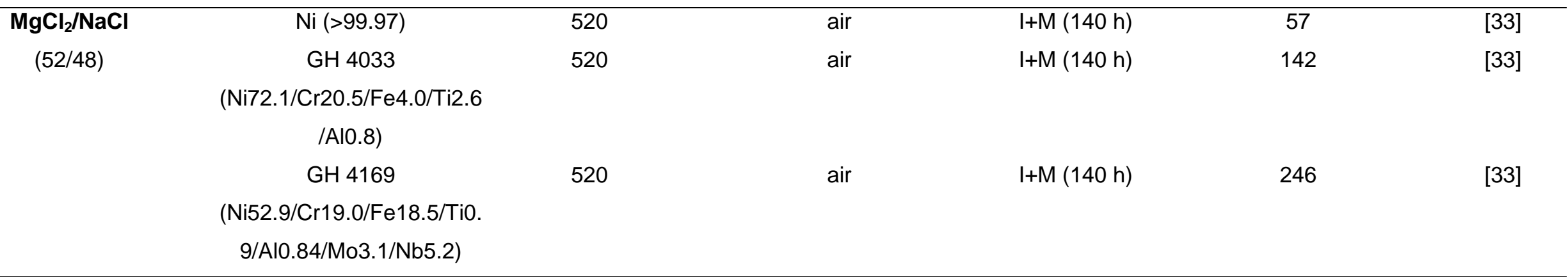

SS: Stainless steel; Ha: Hastelloy; In: Incoloy (Ni wt \% < 50 \%); Inc: Inconel (Ni wt \% > 50 \%).

PDP: potentiodynamic polarization. I+M (immersion time): Immersion test + mass loss. I+MS (immersion time): Immersion test + Microstructural analysis. 


\subsection{Interaction of chloride melts with metallic alloys}

Corrosion mechanisms of metallic alloys in molten chloride salts are complex with different interactions between atmosphere, molten salts, outer corrosion layer, inner corrosion layer and the matrix of metallic alloys [17, 29, 33, 37]. The interaction between atmosphere (covering gases) and molten chlorides has been discussed in section 2.2. In this section, the interaction between molten chlorides with corrosive impurities (e.g. $\mathrm{O}_{2}, \mathrm{Cl}_{2}, \mathrm{HCl}, \mathrm{OH}^{-}$ containing species) and metallic alloys is discussed by reviewing the available literature [17, $29,33,35,37]$.

As summarized in Table 4, research efforts have been made to understand the corrosion mechanism of metallic alloys in molten chloride salts under oxidizing $[17,29,33,37]$ or inert [35] atmosphere. Analysis methods like SEM, EDS, XRD, EAS and electrochemical methods like OCP, LV, EIS were used to analyze the corroded alloys, corrosion products and corrosion behaviors (see Table 4). It can be concluded that the interaction between molten chlorides with corrosive impurities and metallic alloys has two stages (see Figure 8): 1). Oxidation of elements in alloys, 2). Dissolution, precipitation and/or vaporization of oxidized metallic elements. As shown in Table 5, the alloying element $\mathrm{M}$, e.g., Cr, which has a stronger electromotive force (EMF) [38], i.e., lower standard electrode potential in molten chlorides [39], reacts with oxidizing impurities faster. Thus, in theory, the alloying elements ( $\mathrm{Al}, \mathrm{Mn}, \mathrm{Cr}, \mathrm{Fe}, \mathrm{Ni}$ ) oxidized by oxidizing impurities in molten chlorides (e.g. $\mathrm{O}_{2}, \mathrm{Cl}_{2}, \mathrm{HCl}, \mathrm{OH}^{-}$ containing species) to metallic ions tend to be depleted from alloys according to the sequence of $\mathrm{Al}>\mathrm{Mn}>\mathrm{Cr}>\mathrm{Fe}>\mathrm{Ni}$. This phenomenon has been observed and reported in different studies [17, 29, 33, 35, 37]. The metallic ions dissolved in the molten chlorides interact with the ions in the melt further to form, e.g., stable chloride ions $\mathrm{M}_{\mathrm{x}} \mathrm{Cl}_{\mathrm{y}}{ }^{\mathrm{z}} / \mathrm{M}_{\mathrm{x}} \mathrm{Cl}_{\mathrm{y}}{ }^{\mathrm{z+}}$, oxide precipitates $\mathrm{M}_{x} \mathrm{O}_{y}$, gases $\mathrm{M}_{x} \mathrm{Cl}_{y} / \mathrm{M}_{\mathrm{x}} \mathrm{Cl}_{\mathrm{y}} \mathrm{O}_{z}$, which can enhance the oxidation reactions of the alloying elements with the oxidizing impurities in the molten chlorides (stage 1) $[17,29$, $33,35,37]$.

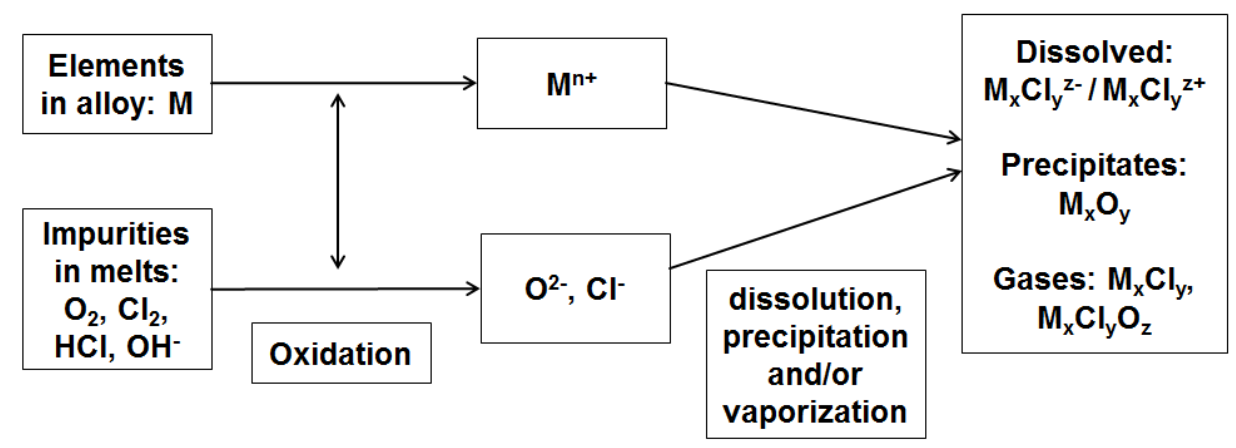

Figure 8: Interaction between molten chlorides with corrosive impurities and metallic alloys. 
Table 4: Corrosion of metallic alloys in molten chlorides.

\begin{tabular}{|c|c|c|c|c|c|}
\hline $\begin{array}{l}\text { Molten chlorides } \\
\text { (wt. \%) }\end{array}$ & Alloys & $\begin{array}{l}\text { Atmosphere } \\
\text { temperature }\end{array}$ & Procedures & Corrosion mechanism & Ref. \\
\hline $\begin{array}{l}\mathrm{CaCl}_{2} / \mathrm{MgCl}_{2} / \mathrm{NaCl} \\
(43.6 / 17.7 / 38.7)\end{array}$ & $\begin{array}{l}\text { Ni-based } \\
\text { commercial } \\
\text { superalloys }\end{array}$ & air $/ 600^{\circ} \mathrm{C}$ & $\begin{array}{l}\text { SEM, EDS, } \\
\text { XRD, TC }\end{array}$ & $\begin{array}{l}\text { Preferential depletion of } \\
\text { Cr and Fe } \\
\text { Intergranular corrosion }\end{array}$ & [29] \\
\hline $\begin{array}{c}\mathrm{MgCl}_{2} / \mathrm{NaCl} \\
(52 / 48)\end{array}$ & $\begin{array}{l}\text { Ni-based } \\
\text { alloys (Ni } \\
52.9-99.97 \\
\text { wt. \%) }\end{array}$ & air $/ 520^{\circ} \mathrm{C}$ & $\begin{array}{l}\text { SEM, EDS, } \\
\text { XRD }\end{array}$ & $\begin{array}{l}\text { Combined effect } \text { of } \\
\text { alloy dissolved as } \\
\text { anode, } \quad \text { preferential } \\
\text { oxidization } \\
\text { chlorination }\end{array}$ & [33] \\
\hline $\begin{array}{l}\mathrm{KCl} / \mathrm{NaCl} \\
(56.1 / 43.9)\end{array}$ & $\begin{array}{l}\text { Stainless } \\
\text { steels }\end{array}$ & $\operatorname{argon} / 750^{\circ} \mathrm{C}$ & $\begin{array}{l}\text { EAS, XRM, } \\
\text { SEM, OCP, } \\
\text { LV, EIS }\end{array}$ & $\begin{array}{l}\text { Intergranular corrosion } \\
\text { Preferential depletion of } \\
\mathrm{Cr} \text {, Fe and Mn. }\end{array}$ & [35] \\
\hline $\begin{array}{l}\mathrm{KCl}-\mathrm{ZnCl}_{2} \\
(69.1 / 30.9)\end{array}$ & $\begin{array}{l}\text { NiAl and } \\
\text { FeAl model } \\
\text { alloys }\end{array}$ & air $/ 400-450^{\circ} \mathrm{C}$ & $\begin{array}{l}\text { SEM, EDX, } \\
\text { XRD, EPMA }\end{array}$ & $\begin{array}{l}\text { Preferential depletion of } \\
\text { Al } \\
\text { Formation of } \mathrm{Al}_{2} \mathrm{O}_{3} \\
\text { within the pores of } \\
\text { corrosion layer }\end{array}$ & [17] \\
\hline $\begin{array}{l}\mathrm{MgCl}_{2} / \mathrm{NaCl} \\
\left(\mathrm{MgCl}_{2} \text { wt. \% 0.0, }\right. \\
48.9,61.0,93.6)\end{array}$ & $\begin{array}{l}\text { GH } 1140 \\
\text { (Ni37.5/Cr21. } \\
\text { 5/Fe35.85/Ti0 } \\
\text {.9/AlO.4/Mo2. } \\
\text { 25/W1.6) }\end{array}$ & air $/ 850^{\circ} \mathrm{C}$ & $\begin{array}{l}\text { SEM, EDS, } \\
\text { XRD }\end{array}$ & $\begin{array}{l}\text { Without } \mathrm{MgCl}_{2} \text { : } \\
\text { dissolution as anode - } \\
\text { oxidizing - peeling off } \\
\text { of oxide film } \\
\text { With } \mathrm{MgCl}_{2} \text { : dissolution } \\
\text { as anode - oxidation - } \\
\text { reduction - peeling off } \\
\text { of oxide film }\end{array}$ & [37] \\
\hline \multicolumn{6}{|c|}{$\begin{array}{l}\text { SEM: scanning electron microscopy, EDS: Energy dispersive spectroscopy, XRD: X-lay } \\
\text { diffraction, TC: Thermodynamic calculation, EAS: Electronic adsorption spectroscopy, XRM: X- } \\
\text { ray microanalysis, OCP: Open circuit potential, LV: Linear voltammetry, EIS: Electrochemical } \\
\text { impedance spectroscopy, EDX: Energy-dispersive analysis, EPMA: Electron probe } \\
\text { microananlysis. }\end{array}$} \\
\hline
\end{tabular}

Table 5: Standard electrode potentials of metallic elements in molten $\mathrm{MgCl}_{2} / \mathrm{KCl} / \mathrm{NaCl}(50 / 20 / 30 \mathrm{~mol} \%)$ at $475^{\circ} \mathrm{C}$ [39].

\begin{tabular}{llllll}
\hline Elements & Al & $\mathrm{Mn}$ & $\mathrm{Cr}$ & $\mathrm{Fe}$ & $\mathrm{Ni}$ \\
\hline $\mathbf{E}_{\mathrm{m}}^{0}(\mathrm{~V})$ & $-1.886\left(\mathrm{Al}^{3+} / \mathrm{Al}\right)$ & $-1.794\left(\mathrm{Mn}^{2+} / \mathrm{Mn}\right)$ & $-1.396\left(\mathrm{Cr}^{2+} / \mathrm{Cr}\right)$ & $-1.183\left(\mathrm{Fe}^{2+} / \mathrm{Fe}\right)$ & -0.792 \\
Vs. $\mathrm{Pt}^{2+} / \mathrm{Pt}$ & & & $-1.131\left(\mathrm{Cr}^{3+} / \mathrm{Cr}\right)$ & $-0.852\left(\mathrm{Fe}^{3+} / \mathrm{Fe}\right)$ & $\left(\mathrm{Ni}^{2+} / \mathrm{Ni}\right)$ \\
\hline
\end{tabular}

Liu et al. [29] investigated the corrosion mechanism of commercial Ni-based ( $\mathrm{Ni}-\mathrm{Cr}-\mathrm{Fe}$ ) superalloys in molten $\mathrm{MgCl}_{2} / \mathrm{CaCl}_{2} / \mathrm{NaCl}$ under air atmosphere at $600^{\circ} \mathrm{C}$ by analyzing the corroded alloys via SEM and EDS and corrosion products via XRD, as well as based on the thermodynamic calculation (TC) of corrosion reactions. The combined effect of dissolution, oxidization and chlorination was considered in the corrosion mechanism of alloys in molten chlorides [29]. During the exposure, oxygen and water in air were continuously dissolved in 
the molten chlorides and reacted with the molten chlorides to form corrosive $\mathrm{HCl}$ and $\mathrm{Cl}_{2}$. These corrosive impurities could accelerate the corrosion of alloys, particularly the $\mathrm{Cr}$ element in the alloys, which has lower standard electrode potential in molten chlorides compared to $\mathrm{Fe}$ and $\mathrm{Ni}$ [39] (see Table 5). In this system, gases like $\mathrm{CrCl}_{4}$ and $\mathrm{CrO}_{2} \mathrm{Cl}_{2}$, and oxide precipitates like $\mathrm{MgCr}_{2} \mathrm{O}_{4}$ and $\mathrm{MgO}$ were considered to be the main products of corrosion reactions based on the thermodynamic calculation [29]. Wang et al. [37] investigated the influence of $\mathrm{MgCl}_{2}$ content on corrosion behavior of metallic alloys in $\mathrm{MgCl}_{2} / \mathrm{NaCl}$ under air atmosphere at $850^{\circ} \mathrm{C}$. It was found that corrosion mechanisms were different with or without $\mathrm{MgCl}_{2}$ in molten chlorides. With $\mathrm{MgCl}_{2}$, a $\mathrm{MgO}$ layer was formed on the alloy surface but could not protect the alloy against corrosion due to its porous structure and peeling off from the alloy surface [37].

Abramov et al. [35] studied corrosion mechanisms of stainless steels (SS 316L, 316Ti and 321) in molten $\mathrm{KCl} / \mathrm{NaCl}$ under inert atmosphere at $750^{\circ} \mathrm{C}$ by analyzing the molten salts and corroded alloys via EAS, SEM, X-ray microanalysis (XRM), as well as using electrochemical methods like open circuit potential (OCP). The dissolution sequence of the alloying elements was determined by combination of EAS for melts with consecutive chemical analysis of quenched melts. Fe, $\mathrm{Cr}$ and $\mathrm{Mn}$ species were in the major products of the anodic dissolution of these studied stainless steels [35]. Moreover, intergranular corrosion of these studied stainless steels in molten chlorides was characterized by electrochemical methods like OCP measurements [35].

Table 3 clearly shows the difficulty to control the corrosion rates of alloys exposed to molten chlorides under oxidizing atmosphere below $15 \mu \mathrm{m} /$ year $\left(\geq 600{ }^{\circ} \mathrm{C}\right.$ ), due to the effect of oxidizing species like $\mathrm{O}_{2}$ and $\mathrm{H}_{2} \mathrm{O}$. Compared to oxidizing atmosphere, the alloys have much lower corrosion rates when exposed to the molten chlorides under inert atmosphere. However, there is still a lack of reliable data and research on the corrosion rates and mechanism of metallic alloys in molten chlorides under inert atmosphere. Thus, more research is essential to cover this gap for realizing the application of molten chlorides in CSP.

\subsection{Corrosion mitigation methods}

Some methods like adding corrosion inhibitors [40-42] in the melts or forming a protective layer on alloys [36, 43-45] have been studied to mitigate the corrosion rates of metallic alloys in molten chlorides at high temperatures.

Cathodic protection is a well-known method for preventing metallic corrosion in aqueous solutions to the previous alloy corrosion potential, either by using impressed current or by using a sacrificial anode. The protection method of using a sacrificial anode has been used 
to reduce the corrosiveness of the molten chloride salts by saturation of a salt with a liquid metal (i.e., LiCl with Li metal [40-41]), or adding active metals such as Mg [42] in the molten chlorides, to reduce the redox potential of the melts, i.e., the concentration of the corrosive impurities like metal-hydroxyl ions and dissolved $\mathrm{O}_{2} / \mathrm{Cl}_{2}$, e.g., via the following reactions:

$$
\begin{gathered}
\mathrm{Mg} \text { (dissolved) }+2 \mathrm{MgOH}^{+} \rightarrow \mathrm{Mg}^{2+}+2 \mathrm{MgO}(\mathrm{s})+1 / 2 \mathrm{H}_{2}(\mathrm{~g}), \\
2 \mathrm{Mg} \text { (dissolved) }+\mathrm{O}_{2} \text { (dissolved) } \rightarrow 2 \mathrm{MgO}(\mathrm{s}), \\
\mathrm{Mg} \text { (dissolved) }+\mathrm{Cl}_{2} \text { (dissolved) } \rightarrow \mathrm{MgCl}_{2}(\mathrm{l})
\end{gathered}
$$

The results of corrosion inhibition experiments in [42] showed that the corrosion rate of the $\mathrm{Ni}$-based (Ni-Cr-Fe) superalloy $\mathrm{Ha} 230$ in $\mathrm{MgCl}_{2}-\mathrm{KCl}$ containing $1.15 \mathrm{~mol} \% \mathrm{Mg}$ under inert atmosphere at $850^{\circ} \mathrm{C}$ showed 35 times lower corrosion than baseline tests with no corrosion inhibitor and met the requirements in industrial applications ( $C R<15 \mu \mathrm{m} / \mathrm{year}$ ). Additional experiments to aggravate corrosion by adding convective flow using a thermosiphon showed that the corrosion rate with convective flow and no $\mathrm{Mg}$ corrosion inhibitor increased by $\mathrm{a}$ factor of 3 [42], whereas thermosiphon tests with the $1.15 \mathrm{~mol} \% \mathrm{Mg}$ corrosion inhibitor reduced corrosion below $15 \mu \mathrm{m} /$ year [42]. However, this method was not studied in real solar power applications.

Besides adding corrosion inhibitors in the melts, surface passivation by forming a protective layer on the alloys is another promising corrosion mitigation approach. Compared to the corrosion inhibitor approach, the alloy with a protective layer could be exposed to both the liquid and the vapor phases of the molten chlorides [43]. In the protective layer development for molten chlorides, research focused on 1). Ceramic layers like $\mathrm{Al}_{2} \mathrm{O}_{3}[36,43-45]$ and $\mathrm{Yttria-}$ stabilized zirconia (YSZ) [45], 2). Metallic layers such as nickel based alloy coatings [44-45]. These studies showed that surface passivation by forming a protective layer on the alloys could reduce the corrosion rates of metallic alloys in molten chlorides significantly. However, there are a number of parameters to be considered for choosing an appropriate coating for a specific substrate material and environment such as corrosion environment, thermal stress (or differences in expansion coefficient of substrate and protective coating), heat resistance, dissolution of the protective layer in the melt [45].

\section{Summary and conclusions}

After reviewing the molten chloride development for CSP and results of studies on hot corrosion of commercial alloys in molten chlorides, it can be concluded that: 
1. Molten chloride mixtures such as $\mathrm{MgCl}_{2}-\mathrm{KCl}-\mathrm{NaCl}$ are promising heat transfer fluid and thermal energy storage media for next generation CSP plants with operation temperatures up to $750^{\circ} \mathrm{C}$.

2. Molten salt temperature, atmosphere over the salt and corrosive impurities in the salt have a significant effect on corrosion rates.

3. Nickel-based superalloys such as Incoloy, Inconel and Hastelloy, which have higher prices due to higher Ni contents, typically have better corrosion resistance in molten chloride salts than stainless steels. However, the conclusion that the resistance of alloys improves with increasing nickel content, is not always true for alloys in contact with molten chlorides.

4. Corrosion of alloys in molten chlorides under air and inert atmosphere has different corrosion mechanisms due to the interaction between atmosphere and molten chlorides. This should be considered in the development of corrosion mitigation methods.

5. Corrosion rates of alloys in molten chlorides can be reduced via salt purification by e.g. stepwise heating, as well as via corrosion mitigation methods such as adding corrosion inhibitors or forming a protective layer on alloys.

6. Electrochemical techniques like cyclic voltammetry, open circuit potential measurement, polarization curves and electrochemical impedance spectroscopy are useful tools for corrosion studies and determination of impurity levels.

The following future works, which help to realize the commercial applications of molten chlorides in next generation CSP, are suggested:

1. Corrosion study of suitable metallic structural materials for molten chlorides up to $750^{\circ} \mathrm{C}$ including aspects such as corrosion in molten salt flow and thermal cycling.

2. Study on durability of the promising protective coatings on alloys,

3. Study on combining the salt purification and corrosion mitigation methods for efficient corrosion control,

4. Study on corrosion mechanism of alloys in molten chlorides with corrosion inhibitors like Mg metal,

5. Development of electrochemical techniques for commercial applications in order to monitor salt quality and corrosion,

6. Development of components and instrumentation (e.g. pumps, valves), as well as their demonstration in lab-scale molten salt test loops. 


\section{Acknowledgments}

This research has been performed within the DLR-DAAD fellowship programme, which is funded by German Academic Exchange Service (DAAD) and German Aerospace Center (DLR).

\section{References}

[1]. Minh N Q. Extraction of metals by molten salt electrolysis: Chemical fundamentals and design factors. Journal of Metals, 1985, 37(1): 28-33

[2]. Fray D J. Emerging molten salt technologies for metals production. Journal of The Minerals, Metals \& Materials Society, 2001, 53(10): 26-31

[3]. Wulandari W, Brooks G A, Rhamdhani M A, Monaghan B J. Magnesium: Current and alternative production routes. In: Proceedings of Chemeca 2010: Engineering at the Edge. Barton, A.C.T.: Engineers Australia, 2010: 347-357

[4]. Mehos M, Turchi C, Vidal J, Wagner M, Ma Z, Ho C, Kolb W, Andraka C, Kruizenga A. Concentrating solar power Gen3 demonstration roadmap. National Renewable Energy Laboratory Technical Report: NREL/TP-5500-67464. 2017, 22-38.

[5]. Kuravi S, Trahan J, Goswami D Y, Rahman M M, Stefanakos E K. Thermal energy storage technologies and systems for concentrating solar power plants. Progress in Energy and Combustion Science, 2013, 39(4): 285-319.

[6]. Zervos A. (ed.) Renewables 2016: Global status report, 2016. Paris: REN21 Secretariat, 2016, 67-69

[7]. Vignarooban K, Xu X, Arvay A, Kannan H K. Heat transfer fluids for concentrating solar power systems - a review. Applied Energy, 2015, 146: 383-396

[8]. Lantelme F, Groult H. (Ed.) Molten salts chemistry: From lab to applications. Oxford: Elsevier LTD, 2013, 415-438

[9]. Li Y, Xu X, Wang X, Li P, Hao Q, Xiao B. Survey and evaluation of equations for thermophysical properties of binary/ternary eutectic salts from $\mathrm{NaCl}, \mathrm{KCl}, \mathrm{MgCl}_{2}, \mathrm{CaCl}_{2}$, $\mathrm{ZnCl}_{2}$ for heat transfer and thermal storage fluids in CSP. Solar Energy, 2017, 152: 5779

[10]. Tian Y, Zhao C Y. A review of solar collectors and thermal energy storage in solar thermal applications. Applied Energy, 2013, 104: 538-553

[11]. Kruizenga A M. Corrosion mechanisms in chloride and carbonate salts. SANDIA Report: SAND2012-7594. 2012, 9-17

[12]. Ozeryanaya I N. Corrosion of metals by molten salts in heat-treatment processes. Metal Science and Heat Treatment, 1985, 27: 184-188 
[13]. Sequeira C A C. High temperature corrosion in molten salts. Molten Salt Forum, 2003, Volume 7, 117-170.

[14]. Lai G Y. (Ed.) High-temperature corrosion and materials applications. Ohio: ASM International, 2007, Chapter 15: Molten salt corrosion, 409-421. ISBN: 9781615030552

[15]. Patel N S, Pavik V, Boca M. High-temperature corrosion behavior of superalloys in molten salts - A review. Critical Review in Solid State and Materials Sciences, 2017, 42(1): 83-97

[16]. Tomkins R P T, Bansal N P. Gases in molten salts, a volume in IUPAC solubility data series. Oxford: Pergamon Press, 1991, Volume 45/46, 61, 114-176, 220-245, 325-339, 353-357. ISBN: 9780080307350

[17]. Li Y S, Spiegel M. Models describing the degradation of FeAl and NiAl alloys induced by $\mathrm{ZnCl}_{2}-\mathrm{KCl}$ melt at $400-450^{\circ} \mathrm{C}$. Corrosion Science, 2004, 46: 2009-2023

[18]. Maksoud L, Bauer T. Experimental investigation of chloride molten salts for thermal energy storage applications. In: Proceedings of 10th International Conference on Molten Salt Chemistry and Technology, Shenyang, China, 2015, 273-280

[19]. Kipouros G J, Sadoway D R. A thermochemical analysis of the production of anhydrous $\mathrm{MgCl}_{2}$. Journal of Light Metals, 2001, 1(2): 111-117

[20]. Maricle D L, Hume D N. A new method for preparing hydroxide - free alkali chloride melts. Journal of The Electrochemical Society, 1960, 107(4): 354-356

[21]. Skar R A. Chemical and electrochemical characterisation of oxide/hydroxide impurities in the electrolyte for magnesium production. Dissertation for the Doctoral Degree. Trondheim: Norwegian University of Science and Technology (NTNU), 2001, 26

[22]. Gussone J. Schmelzflusselektroytische Abscheidung von Titan auf Vertärkungsfasern zur Herstellung von Titanmatrixverbundwerkstoffen. Dissertation for the Doctoral Degree. Aachen: RWTH Aachen University, 2012, 56-80 (in German)

[23]. Ding W, Bonk A, Gussone J, Bauer T. Electrochemical measurement of corrosive impurities in molten chlorides for thermal energy storage. Journal of Energy Storage, 2018, 15: 408-414

[24]. Ding W, Bonk A, Gussone J, Bauer T. Cyclic voltammetry for monitoring corrosive impurities in molten chlorides for thermal energy storage. Energy Procedia, 2017, 135: 82-91

[25]. Ding W, Bonk A, Gussone J, Bauer T. Electrochemical method for monitoring corrosive impurities in molten $\mathrm{MgCl}_{2} / \mathrm{KCl} / \mathrm{NaCl}$ salts for thermal energy storage. In: Proceedings of 11th International Renewable Energy Storage Conference (IRES 2017), Düsseldorf Germany, 2017, Paper-Nr: IRES2017-141 
[26]. Gaune-Escard M. (ed.) Molten salts: From fundamentals to applications. NATO Science Series (Series II: Mathematics, Physics, and Chemistry), volume 52. Dordrecht: Springer, 2002, 283-285

[27]. Mohamedi M, Borresen B, Haarberg G M, Tunold R. Anodic behavior of carbon electrodes in $\mathrm{CaO}-\mathrm{CaCl}_{2}$ melts at $1123 \mathrm{~K}$. Journal of The Electrochemical Society, 1999, 146(4): 1472-1477

[28]. Brookes H C. Voltammetric investigations of $\mathrm{CaCl}_{2}: \mathrm{KCl}$ melts at $700^{\circ} \mathrm{C}$. Journal of The Electrochemical Society, 1988, 135(2): 373-377

[29]. Liu B, Wei X, Wang W, Lu J, Ding J. Corrosion behavior of Ni-based alloys in molten $\mathrm{NaCl}-\mathrm{CaCl}_{2}-\mathrm{MgCl}_{2}$ eutectic salt for concentrating solar power. Solar Energy Materials \& Solar Cells, 2017, 170: 77-86

[30]. Vignarooban K, Pugazhendhi P, Tucker C, Gervasio D, Kannan A M. Corrosion resistance of Hastelloys in molten metal-chloride heat-transfer fluids for concentrating solar power applications. Solar Energy, 2014, 103: 62-69

[31]. Vignarooban K, Xu X, Wang. K, Molina E E, Li P, Gervasio D, Kannan A M. Vapor pressure and corrosivity of ternary metal-chloride molten-salt based heat transfer fluids for use in concentrating solar power systems. Applied Energy, 2015, 159: 206-213

[32]. Gomez-Vidal J C, Tirawat R. Corrosion of alloys in a chloride molten salt ( $\mathrm{NaCl}-\mathrm{LiCl})$ for solar thermal technologies. Solar Energy Materials \& Solar Cells, 2016, 157: 234-244

[33]. Wang J W, Zhang C Z, Li Z H, Zhou H X, He J X, Yu J C. Corrosion behavior of nickel-based superalloys in thermal storage medium of molten eutectic $\mathrm{NaCl}-\mathrm{MgCl}_{2}$ in atmosphere. Solar Energy Materials \& Solar Cells, 2017, 164: 146-155

[34]. Abramov A V, Polovov I B, Volkvich V A, Rebrin O I, Denisov E I, Griffiths T R. Corrosion of austenitic steels and their components in vanadium-containing chloride melts. ECS Transactions, 2012, 50(11): 685-698

[35]. Gaune-Escard M, Haarberg G M. (ed.) Molten salts chemistry and technology. Chichester, UK: John Wiley \& Sons, Ltd, 2014, 427-448

[36]. Gomez-Vidal J C, Fernandez A G, Tirawat R, Turchi C, Huddleston W. Corrosion resistance of alumina-forming alloys against molten chlorides for energy production. II: Pre-oxidation treatment and isothermal corrosion tests. Solar Energy Materials \& Solar Cells, 2017, 166: 222-233

[37]. Wang J, Zhou H, Zhang C, Liu W, Zhao B. Influence of $\mathrm{MgCl}_{2}$ content on corrosion behavior of $\mathrm{GH} 1140$ in molten $\mathrm{NaCl}-\mathrm{MgCl}_{2}$ as thermal storage medium. Solar Energy Materials and Solar Cells, in Press, https://doi.org/10.1016/i.solmat.2017.11.014

[38]. Hamer W J, Malmberg M S, Rubin B. Theoretical electromotive forces for cells containing a single solid or molten chloride electrolyte. Journal of The Electrochemical Society, 1956, 103(1): 8-16 
[39]. Plambeck J A. Electromotive force series in molten salts. Journal of Chemical \& Engineering Data, 1967, 12(1): 77-82

[40]. Indacochea J E, Smith J L, Litko K R, Karell E J, Rarez A G. High-temperature oxidation and corrosion of structural materials in molten chlorides. Oxidation of Metals, 2001, 55(1-2): 1-16

[41]. Indacochea J E, Smith J L, Litko K R, Karell E J. Corrosion performance of ferrous and refractory metals in molten salts under reducing conditions. Journal of Materials Research, 1999, 14(5): 1990-1995

[42]. Garcia-Diaz B L, Olson L, Martinez-Rodriguez M, Fuentes R, Colon-Mercado H, Gray J. High temperature electrochemical engineering and clean energy systems. Journal of the South Carolina Academy of Science, 2016, 14(1), Article 4, 11-14

[43]. Gomez-Vidal J C, Fernandez A G, Tirawat R, Turchi C, Huddleston W. Corrosion resistance of alumina-forming alloys against molten chlorides for energy production. I: Pre-oxidation treatment and isothermal corrosion tests. Solar Energy Materials \& Solar Cells, 2017, 166: 222-233

[44]. Gomez-Vidal J C. Corrosion resistance of MCrAlX coatings in a molten chloride for thermal storage in concentrating solar power applications. Nature Partner Journal Materials Degradation, 2017, 7: 1-9

[45]. Azarbayjani K, Rizvi G, Foroutan F. Evaluating effects of immersion tests in molten copper chloride salts on corrosion resistant coatings. International Journal of Hydrogen Energy, 2016, 41: 8394-8400 